Rev. Inst. Flor . v. 27 n. 1 p. $19-29$ jun. 2015

http://dx.doi.org/10.4322/rif.2015.002

ISSN impresso 0103-2674/on-line 2178-5031

\title{
BASIC SPECIFIC GRAVITY AND ANATOMY OF Peltophorum dubium WOOD AS A FUNCTION OF PROVENANCE AND RADIAL POSITION ${ }^{1}$
}

\section{DENSIDADE APARENTE E ANATOMIA DA MADEIRADE Peltophorum dubium EM FUNÇÃO DA PROCEDÊNCIA E POSIÇÃO RADIAL}

\author{
Israel Luiz de LIMA²; Eduardo Luiz LONGUI',3; \\ Cintya CERATO²; Miguel Luiz Menezes FREITAS²; \\ Sandra Monteiro Borges FLORSHEIM ${ }^{2}$; Antonio Carlos Scatena ZANATTO²
}

\begin{abstract}
We studied the wood of Peltophorum dubium (Spreng.) Taub. (Fabaceae), popularly known in Brazil as canafistula, from two seed provenances with different climates. The trees were planted in a third place and cut when 28 years old. Based on differences in seed origins, we hypothesized that some differences would be observed in wood density and anatomical features between provenances and that the radial variation pattern would also differ. However, we did not observe any differences in basic specific gravity or anatomical features between the provenances, which may partly be explained by the conservative nature of wood compared with the external characteristics more susceptible to environmental stresses. In fact, based on the literature and our previous findings, radial variation in P. dubium was similar to that found in many native species, including, for example, increase in basic specific gravity, length and wall thickness of the fibers, increase in vessel diameter and decrease in vessel frequency toward the bark. Based on our results, it can be concluded that $P$. dubium has high plant adaptability in different locations and that consistency in the quality of its wood can be maintained between provenances, with concomitant implications for both production and use.
\end{abstract}

Keywords: canafístula, genetic conservation; pith-bark variation; tropical woods; wood anatomy; wood density; wood quality.

RESUMO - Estudamos a madeira de Peltophorum dubium (Spreng.) Taub. (Fabaceae), popularmente conhecida no Brasil como canafístula, a partir de duas procedências de sementes com diferentes climas. As árvores foram plantadas em um terceiro lugar e cortadas aos 28 anos. Com base nas diferentes origens das sementes, hipotetizamos que diferenças seriam observadas na densidade aparente e características anatômicas da madeira entre as procedências e que o padrão de variação radial também diferisse. No entanto, não foram observadas quaisquer diferenças na densidade aparente ou nas características anatômicas entre as procedências, o que pode em parte ser explicado pela natureza conservativa da madeira em comparação com as características externas mais sensíveis a estresses ambientais, como as folhas. Com base na literatura e em nossos resultados anteriores, a variação radial em P. dubium foi semelhante à encontrada em muitas espécies nativas, incluindo, por exemplo, aumento na densidade aparente, comprimento e espessura da parede das fibras, aumento no diâmetro e diminuição na frequência de vasos na direção da casca. Concluímos que P. dubium tem alta adaptabilidade em diferentes locais e que a consistência na qualidade de sua madeira pode ser mantida entre procedências, com implicações concomitantes, tanto para produção quanto para a utilização.

Palavras-chave: canafístula, conservação genética; variação medula-casca; madeiras tropicais; anatomia da madeira; densidade da madeira; qualidade da madeira.

\footnotetext{
1 Received for analysis on 08.12.14. Accepted for publication on 03.03.15. Published on-line on 23.06.15. ${ }^{2}$ Instituto Florestal, Rua do Horto, 931, 02377-000 São Paulo, SP, Brasil.

${ }^{3}$ Corresponding author: Eduardo Luiz Longui - edulongui@gmail.com
} 


\section{INTRODUCTION}

To expand the Brazilian forest sector, it is necessary a better understand of the quantity and quality of potential wood-producing forest species. Native species experiments with the effect of provenances on progenies, base population tests and seed orchards with saplings of various species are used for ex situ conservation and can provide results related to the development of planting strategies, as well as materials for studies on wood quality (Siqueira et al., 2000). These experiments may also provide the basis for future production of seeds not inbred. The results may contribute to 1) genetic conservation through progeny tests, indicative of the potential for conservation of germplasm banks (ex situ), 2) seeds planning and production for environmental restoration of degraded areas and 3) knowledge about wood quality among provenances.

Peltophorum dubium is a species with the potential for this type of research, it is native, not endemic species in Brazil, with geographical distribution in the Northeast (Bahia, Paraiba, Pernambuco, Sergipe), Midwest (Federal District, Mato Grosso do Sul), Southeast (Espírito Santo, Minas Gerais, Rio de Janeiro, São Paulo), South (Paraná, Santa Catarina), on Caatinga, Cerrado, Mata Atlântica, Pantanal (Lewis 2014). According to Carvalho (2003), P. dubium, popularly known as "canafistula", is a promising species for wood production because it presents an average annual increment at about $19.60 \mathrm{~m}^{3} \cdot \mathrm{ha}^{-1} \cdot \mathrm{year}^{-1}$, with acceptable silvicultural performance, and it is recommended for pure or mixed stands. P. dubium wood has specific gravity (15\%) between 0.69 and $0.90{\mathrm{~g} . \mathrm{cm}^{-3}}^{-}$and basic density between 0.53 and $0.65 \mathrm{g.cm}^{-3}$. The sapwood is pinkish-clear and slightly yellowish, and the heartwood is pinkish-brown to pinkish-beige-dark. The wood is prone to warping during drying, but it is long-lasting when in dry places with moderate resistance to decay (Mainieri and Chimelo, 1989; Lorenzi, 2002; Carvalho, 2003; Paula and Alves, 2007). P. dubium wood is not widely used in Brazil, but it could, for example, be used in construction, carpentry, cooperage, car bodies, railway sleepers or paper production (Lorenzi, 2002; Paula and Alves, 2007).

According to Panshin and Zeeuw (1964), the variation in wood characteristics from pith to bark can decrease or increase its properties. This variability is based on the differences between juvenile and mature wood. Juvenile wood is characterized by a gradual change in cell features and wood properties, whereas mature wood has greater homogeneity. According to Lachenbruch et al. (2010), in trees, wood located in the pith is commonly called juvenile wood based on the young age of cambium at the time of formation; then a transition period occurs before mature wood is formed. It is not precisely known when juvenile wood stops producing and mature wood starts. However, during the gradual radial variation from pith to bark, wood properties are stabilized and can decrease in some portions (Bendtsen and Senft, 1986). The main bases of comparison between juvenile and mature wood involve variations in anatomical features, as well as physicomechanical and chemical properties toward the bark. In particular, some of these anatomical wood features include fiber length, microfibril angle, cell-type proportions, cell diameter, and wall thickness. In our study we evaluated the fiber length, fiber wall thickness, vessel element length, vessel diameter and vessel frequency prepared by macerated wood, and transverse and longitudinal sections, since these characteristics can give us parameters for wood quality. Other properties, such as wood density, mechanical resistance, dimensional stability and response to humidity, result from anatomical changes and chemicals content (Silva, 2000).

Thus, our goal was to study radial variation in the context of density and anatomy in Peltophorum dubium planted in a third place far from the seed provenances and with different climates. Based on differences in seed origins, we hypothesized that some differences would be observed in wood density and anatomical features between provenances and that the radial variation pattern would also differ. 


\section{MATERIALS AND METHODS}

In 1982, the São Paulo Forest Institute in Brazil implemented a germplasm bank of Peltophorum dubium at the Luiz Antônio Experimental Station, Luiz Antônio City, São Paulo, to ex-situ conservation of some populations of this species (Gurgel-Garrido et al., 1997). The planting was located at latitude $21^{\circ} 40^{\prime} \mathrm{S}$, longitude $47^{\circ} 49^{\prime} \mathrm{W}$, and at an altitude of $550 \mathrm{~m}$. The average annual rainfall in this location is $1,365 \mathrm{~mm}$, with sandy textured soils characterized by the formation of oxisols. The climate is Cwa in accordance with the Köppen system (Ventura et al., 1965/1966).

The location of the two seed collecting areas and the study area may be viewed in Figure 1.
Alvorada do Sul - AS municipality, Paraná state with average annual precipitation $=1,295 \mathrm{~mm}$, average annual temperature $=22.2{ }^{\circ} \mathrm{C}$ and Bauru $-\mathrm{BA}$ municipality, São Paulo state with average annual precipitation $=1,209 \mathrm{~mm}$, average annual temperature $=21.1{ }^{\circ} \mathrm{C}$ (Climate-Data.Org, 2015). The experimental design was randomized with two parcels, one for each seed origin at a spacing of $3 \times 2$ m (Figure 2) (Gurgel-Garrido et al., 1997). Five tree samples were selected from each provenance (Table 1), and from each tree, we collected a disc having a thickness of $7 \mathrm{~cm}$ in diameter at breast height - DBH of $1.30 \mathrm{~m}$ from the soil. From each disc, we used a band saw to cut a strip for anatomy $(2 \times 2 \times 2 \mathrm{~cm})$ and basic specific gravity analysis $(2 \times 2 \times 3 \mathrm{~cm})$ from pith to bark - 0 , 33, 66, 100\% (Figure 3).

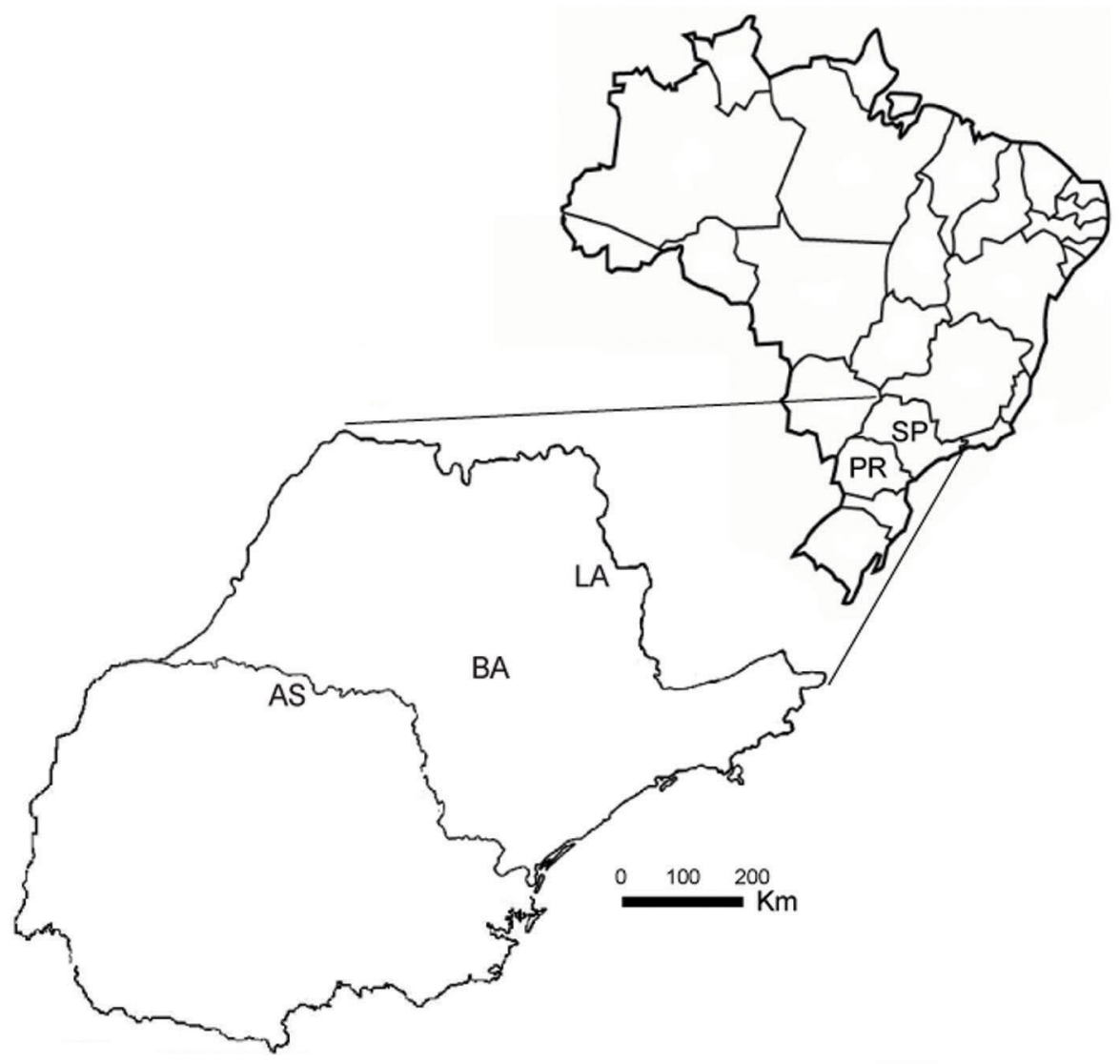

Figure 1. Location of two seed collection areas, Alvorada do Sul - AS and Bauru - BA and the study area, Luiz Antônio - LA, in São Paulo state, Brazil.

Figura 1. Localização das áreas de coleta de sementes, Alvorada do Sul -AS e Bauru - BA, e a área de estudo, Luiz Antônio - LA, no Estado de São Paulo, Brasil. 

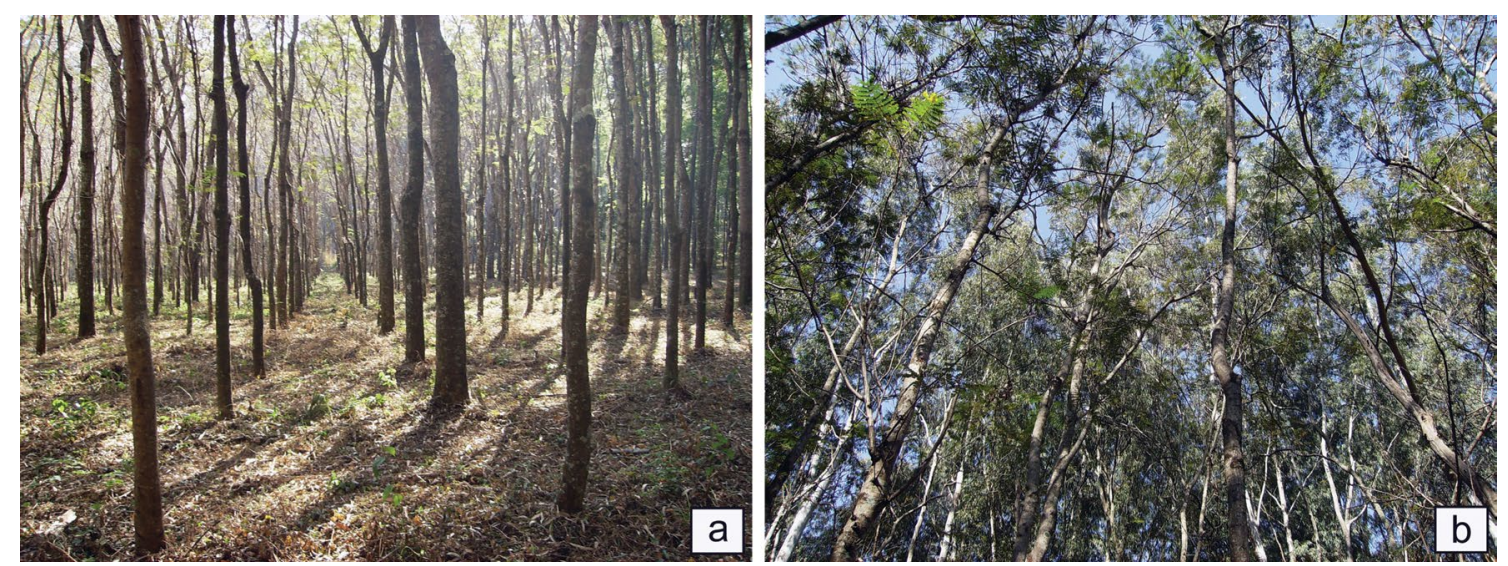

Figure 2. Overview of the P. dubium planting in Luiz Antônio Experimental Station, Luiz Antônio City, São Paulo. (a) trees stems (b) trees canopies.

Figura 2. Visão geral do plantio de P. dubium na Estação Experimental de Luiz Antônio, São Paulo. (a) troncos de árvores (b) copas das árvores.

Table 1. Dendrometric data of 28-year-old Peltophorum dubium trees according to the provenance.

Tabela 1. Dados dendrométricos das árvores de Peltophorum dubium de acordo com a procedência.

\begin{tabular}{|c|c|c|c|c|c|}
\hline \multicolumn{3}{|c|}{ Alvorada do Sul } & \multicolumn{3}{|c|}{ Bauru } \\
\hline Tree & Height (m) & DBH $(\mathrm{cm})$ & Tree & Height (m) & $\mathrm{DBH}(\mathrm{cm})$ \\
\hline 1 & 17.0 & 18.0 & 1 & 18.5 & 16.0 \\
\hline 2 & 16.0 & 17.5 & 2 & 15.8 & 18.0 \\
\hline 3 & 12.6 & 14.0 & 3 & 16.8 & 17.5 \\
\hline 4 & 14.7 & 18.0 & 4 & 15.3 & 17.0 \\
\hline 5 & 14.6 & 18.0 & 5 & 14.3 & 15.0 \\
\hline Mean & 15 & 17.1 & Mean & 16.1 & 16.7 \\
\hline
\end{tabular}

$\mathrm{DBH}=$ diameter at breast height. 


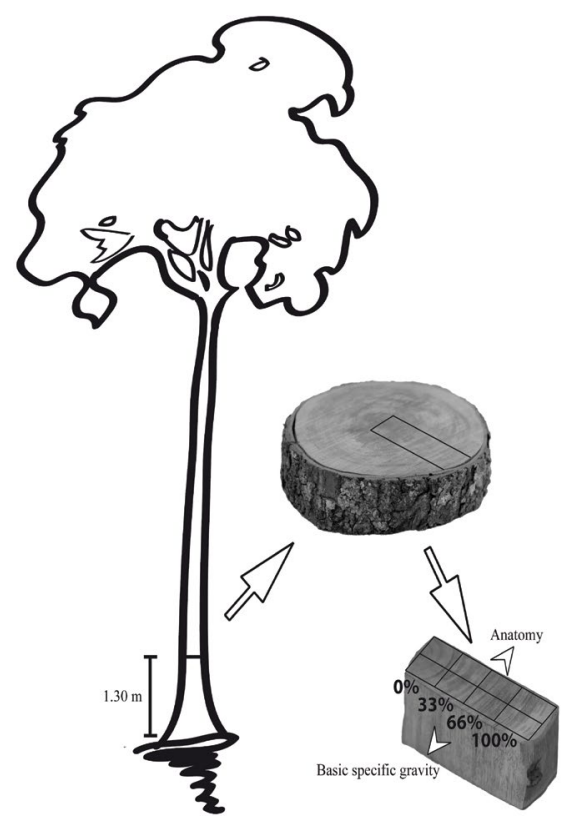

Figure 3. Sampling for wood anatomy and basic specific gravity.

Figura 3. Amostragem para anatomia da madeira e densidade básica.

For basic specific gravity was determination, samples of $2 \times 2 \times 3 \mathrm{~cm}$ were saturated by treatment with a vacuum system for $48 \mathrm{~h}$ to obtain green volume of wood. In sequence, the samples were dried in a laboratory kiln to determine the oven-dried mass at $102 \pm 3{ }^{\circ} \mathrm{C}$ (Glass and Zelinka, 2010). For calculation, we used the following expression:

$$
B S G=\frac{P_{s}}{P_{u}-P_{i}},
$$

where BSG is basic specific gravity $\left(\mathrm{g} \mathrm{cm}^{-3}\right)$, Ps is dry mass $(\mathrm{g}), \mathrm{Pu}$ is saturated mass $(\mathrm{g})$, and $\mathrm{Pi}$ is immersed mass $(\mathrm{g})$.

We cut small pieces from the sample sides and prepared macerations according to the modified Franklin method (Berlyn and Miksche, 1976). Then, samples were boiled in water, glycerin and alcohol (4:1:1) and transverse and tangential longitudinal sections (16-20 $\mu \mathrm{m}$ in thickness) were obtained with a sliding microtome. Sections were stained with a $1 \%$ solution of safranin and mounted in a solution of water and glycerin (1:1) on slides (Johansen, 1940). The terminology and characterization of wood followed the IAWA list (IAWA Committee, 1989).
All anatomical measurements were obtained from a microscope (Olympus CX 31) equipped with a camera (Olympus Evolt E330) and a computer with image analyzer software (Image-Pro 6.3). We determine the fiber length, fiber wall thickness, vessel element length, vessel diameter and vessel frequency.

Statistical tests were performed using SAS \& software for Windows (SAS, 1999). We performed the analysis ofvariance ( $\mathrm{F}$ test) according to a completely randomized design, adopting the $2 \times 4$ factorial (provenances $\mathrm{x}$ radial position). When a significant difference was observed, we employed the Tukey test at $(\mathrm{p}<0.05)$. We also used linear regression to show relationships between anatomical features, basic specific gravity and radial positions. Results with $\mathrm{p}<0.05$ were considered significant.

\section{RESULTS AND DISCUSSION}

Between provenances, we found no significant differences among the studied variables. Only vessel element length - VEL was found to be significantly different among the radial positions (Table 2). By F test, we observed no significant interaction between provenance and radial position. 
Table 2. Analysis of variance of basic specific gravity - BSG, fiber length - FL, fiber wall thickness - FWT, vessel element length - VEL; vessel diameter - VD and vessel frequency - VF of 28-year-old Peltophorum dubium.

Tabela 2. Análise de variância da densidade básica - BSG, comprimento da fibra - FL, espessura da pareda da fibra - FWT, comprimento do elemento de vaso - VEL, diâmetro do vaso - VD e frequência do vaso - VF de Peltophorum dubium aos 28 anos de idade.

\begin{tabular}{|c|c|c|c|c|c|c|c|}
\hline \multirow[b]{2}{*}{ Causes of variation } & \multirow[b]{2}{*}{ GL } & \multicolumn{6}{|c|}{ Mean squares } \\
\hline & & $\begin{array}{c}\text { BSG } \\
\left(\text { g.cm } \mathrm{cm}^{-3}\right)\end{array}$ & $\begin{array}{c}\mathrm{FL} \\
(\mu \mathrm{m})\end{array}$ & $\begin{array}{l}\text { FWT } \\
(\mu \mathrm{m})\end{array}$ & $\begin{array}{l}\text { VEL } \\
(\mu \mathrm{m}) \\
\end{array}$ & $\begin{array}{l}\text { VD } \\
(\mu \mathrm{m})\end{array}$ & $\begin{array}{c}\mathrm{VF} \\
\left(\text { vessels. } \mathrm{mm}^{-2} \text { ) }\right.\end{array}$ \\
\hline Provenance $(\mathrm{P})$ & 1 & $0.0024^{\text {n.s. }}$ & $4778^{\text {n.s. }}$ & $0.0093^{\text {n.s. }}$ & $48.75^{\text {n.s. }}$ & $19.20^{\text {n.s. }}$ & $0.27^{\text {n.s. }}$ \\
\hline Radial position (RP) & 3 & $0.0112^{*}$ & $43872 * *$ & $2.29 * *$ & 670n.s. & $2782 * *$ & $3.79 * *$ \\
\hline$(\mathrm{P}) \mathrm{x}(\mathrm{RP})$ & 3 & $0.0024^{\text {n.s. }}$ & $1321^{\text {n.s. }}$ & $0.2368^{\mathrm{n} . \mathrm{s}}$ & $271^{\text {n.s. }}$ & $32.18^{\text {n.s. }}$ & $0.85^{\text {n.s. }}$ \\
\hline Residual & 32 & 0.0034 & 6301 & 0.3517 & 1324 & 182 & 0.59 \\
\hline Mean & & 0.46 & 854 & 3.81 & 357 & 139 & 3.89 \\
\hline CV (\%) & & 12.56 & 9.28 & 15.58 & 10.19 & 9.71 & 19.71 \\
\hline
\end{tabular}

n.s. not significant, ${ }^{*}$ at the $5 \%$ significance level, ${ }^{* *}$ at the $1 \%$ significance level and $\mathrm{CV}$, coefficient of variation.

P. dubium presented an average value of $0.46 \mathrm{~g} . \mathrm{cm}^{-3}$ for basic specific gravity (Table 2), which is lower than the value reported by Silva et al. (1983), from 0.53 to 0.65 g.cm ${ }^{-3}$, and Vivian et al. (2010), who described BSG of 0.65 g.cm $\mathrm{cm}^{-3}$ in 10 -year-old $P$. dubium. The difference in findings in these studies may be the result of differences in the age of the wood studied because wood density is influenced by the tree's age (Richter, 2015). Based on samples taken from natural forests, this influence was highlighted in $P$. dubium by Paula $(1983 ; 1985)$ who found specific gravity of $0.51{\mathrm{~g} . \mathrm{cm}^{-3}}^{-3}$ for young trees and $0.75 \mathrm{~g} . \mathrm{cm}^{-3}$ for mature trees. Differences could also be explained by growing conditions because the trees we investigated derived from homogeneous planting, while those reported in the literature derived from natural growth conditions. We emphasize that Paula (1985) reported specific gravity of $0.51 \mathrm{~g} . \mathrm{cm}^{-3}$ for young trees, which is roughly the same value we found in wood next to the bark $\left(0.50{\mathrm{~g} . \mathrm{cm}^{-3}}^{-3}\right)$ of wood formed at 28 years of age, and, in our opinion, this is already mature wood. Thus, we suggest that planting conditions influenced basic specific gravity. This result is not the same for other native species. For example: Marques et al. (2012) found the same wood density values when native forest wood was compared with reforestation wood from 30-year-old Caesalpinia echinata.
Furthermore, density depends on anatomical features, which also vary with age (Panshin and Zeeuw, 1964). Our group has studied other Brazilian native species planted in Luiz Antônio, and we also observed anatomical variations influencing variations in wood density with age (e.g., Lima et al. (2011a) and Lima et al. (2011b) in Balfourodendron riedelianum and Cariniana legalis, respectively, and Longui et al. (2011) in Gallesia integrifolia and Longui et al. (unpublished data) in Myracrodruon urundeuva). The average values of anatomical features also varied when compared to the study of Paula (1983) who found fiber to be $978 \mu \mathrm{m}$ in length, wall thickness of $4.62 \mu \mathrm{m}$, vessels $169 \mu \mathrm{m}$ in diameter, 4 vessels. $\mathrm{mm}^{-2}$, slightly higher values than those found in our study (Table 2), which is, again, possibly related to the age difference of the trees.

To calculate the average values of radial position, we used the data set related to BA + AS samples (see Table 2). Basic specific gravity from AS provenance does not significantly differ from that of BA provenance (Figure 4a). Similarly, fiber features (Figure $4 b-c$ ) and vessel features (Figure $5 \mathrm{a}-\mathrm{c})$ were not influenced by seed provenance. Different results were obtained by Lima et al. (2011b) for Cariniana legalis, Lima et al. (2011a) for Balfourodendron riedelianum and Longui et al. (2011) for Gallesia integrifolia, where provenance did influence wood density and anatomical features. 

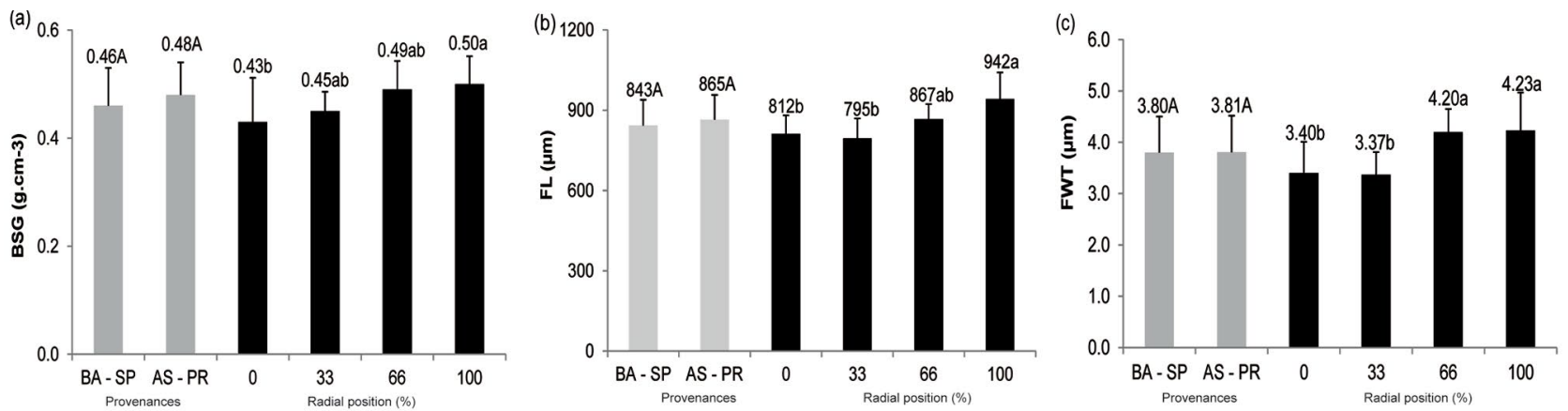

Figure 4. Means of (a) basic specific gravity - BSG (b) fiber length - FL and (c) fiber wall thickness - FWT of 28-year-old Peltophorum dubium (between provenances in gray, and as a function of radial position in black). Standard deviations and means followed by different letters differ at $(\mathrm{p}<0.05)$.

Figure 4. Médias da (a) densidade básica - BSG (b) comprimento da fibra - FL e (c) espessura da parede da fibra - FWT de Peltophorum dubium (entre procedências em cinza e em função da posição radial em preto). Desvios-padrão e médias seguidas por letras distintas diferem em $(\mathrm{p}<0,05)$.
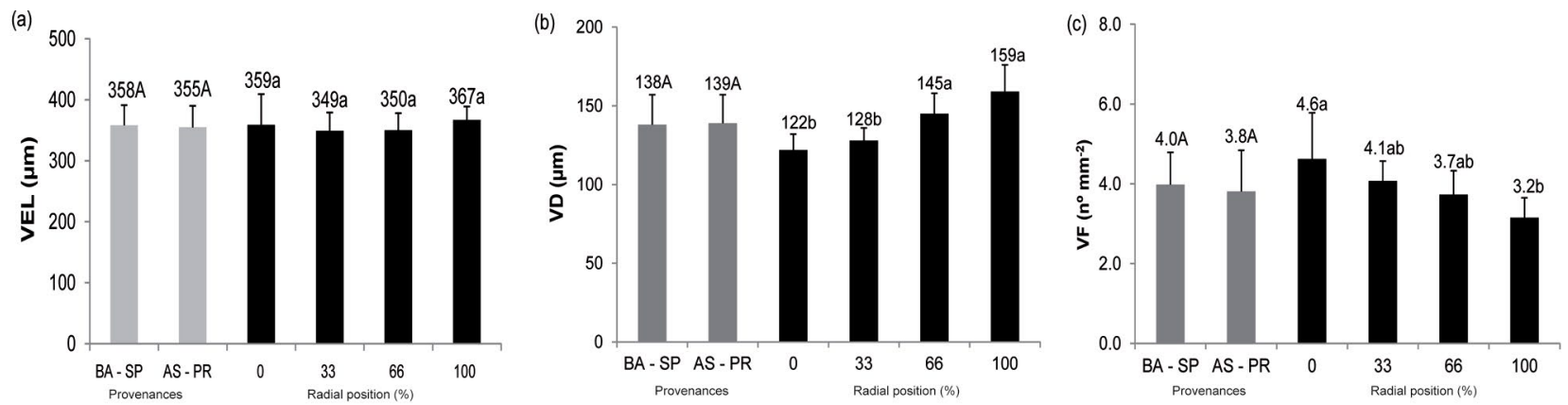

Figure 5. Means of (a) vessel element length - VEL (b) vessel diameter - VD and (c) vessel frequency - VF of 28-year-old Peltophorum dubium (between provenances in gray, and as a function of radial position in black). Standard deviations and means followed by different letters differ at $(\mathrm{p}<0.05)$.

Figure 5. Médias do (a) comprimento do elemento de vaso - VEL (b) diâmetro do vaso - VD e (c) frequência do vaso - VF de Peltophorum dubium (entre procedências em cinza em função da posição radial em preto). Desvios-padrão e médias seguidas por letras distintas diferem em $(\mathrm{p}<0,05)$. 
In the radial direction, basic specific gravity and fiber length showed a gradual increase toward the bark, and fiber wall thickness increased from $33 \%$ to $66 \%$ radial position and remained the same in the bark (Figure 4a-c). The same pattern of basic specific gravity radial increase was noted in both provenances despite differences in height and $\mathrm{DBH}$, which can be attributed to trees having the same age. Williamson and Wiemann (2011) studied specific gravity radial variation in 30 trees from 12 species, all native tropical angiosperms trees from natural forest, and concluded that radial increases in specific gravity are dependent on tree age, not tree size. According to Panshin and Zeeuw (1964), the increase in wood density toward the bark results from juvenile wood formation in the early years and subsequent increase of mature wood, over time, near the bark. This variation results from wood produced by a cambium at one height that increases in age with each growth ring (Gartner, 1995).

The variation in density toward the bark is also quite common in Brazilian native woods, and we have observed this phenomenon in all of our studies (Lima et al., 2011a; Lima et al., 2011b; Longui et al., 2011). Hietz et al. (2013) reported hundreds of species in Panamanian and Ecuadorian forests and noted that the wood density was negatively related to tree growth and mortality and that wood density tended to increase towards the bark on trees with low initial density and decrease in the direction of the bark on trees with high initial density. The authors suggest that these variations occur in response to the mechanical requirements during ontogeny.

Vessel element length did not change toward the bark (Figure 5a), while vessel diameter increased and vessel frequency decreased in the same direction (Figure 5b-c e Figure 6a-b). This result was also verified by regression (linear) analysis (Figure 7a-b). We observed the same pattern with two other native Brazilian trees, Cariniana legalis (Lima et al., 2011) and Gallesia integrifolia (Longui et al., 2011). Similar results were found for many species (Gartner, 1995; Baas et al., 2004). Christensen-Dalsgaard et al. (2008) studied vessel radial variation in buttressed tree root systems and concluded that the anatomical radial patterns do not occur simply by cambial aging; instead, they result from local mechanical requirements. Similarly, we understand that radial anatomical variations of vessels provide a tradeoff between water transport and mechanical support.
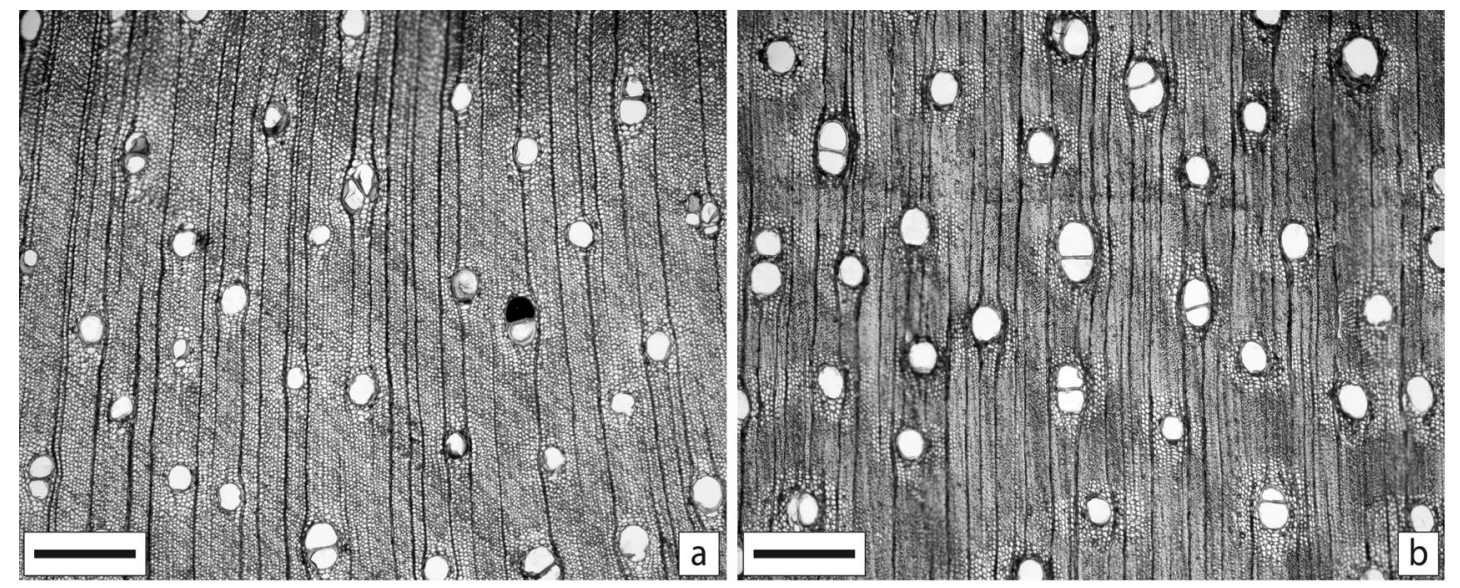

Figure 6. Photomicrographs of Peltophorum dubium wood. (a) transverse section of the pith region ( $0 \%$ (b) transverse section of the bark region $(100 \%)$. Scale bar $=500 \mu \mathrm{m}$.

Figura 6. Fotomicrografias da madeira de Peltophorum dubium wood. (a) seção transversal da região da medula (0\%) (b) seção transversal da região da casca $(100 \%)$. Barra de escala $=500 \mu \mathrm{m}$. 

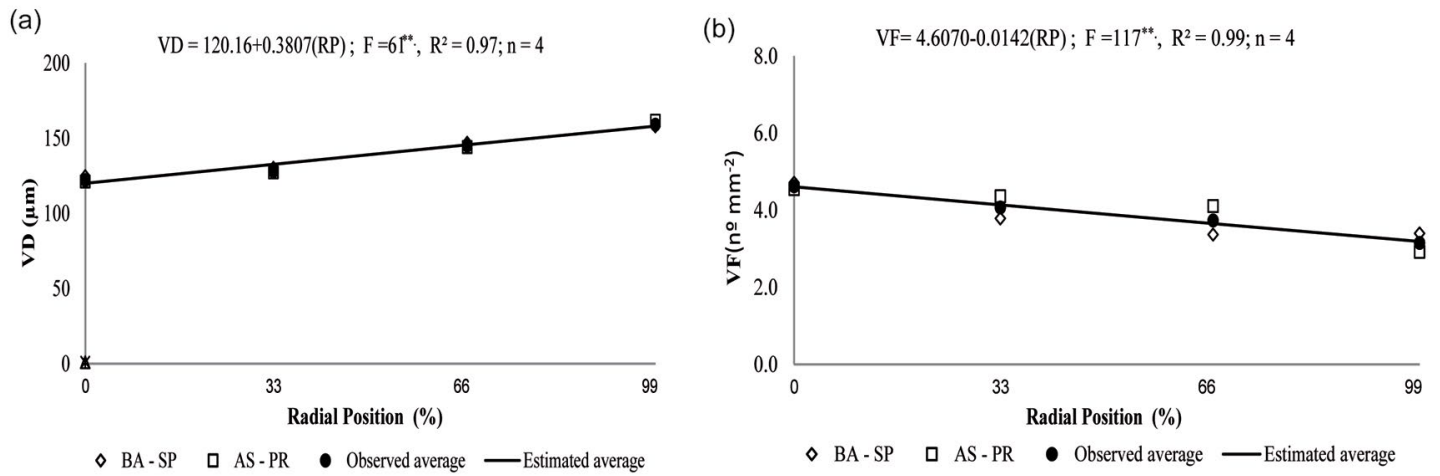

Figure 7. Relationship between vessel features as a function of radial position of 28-year-old Peltophorum dubium. (a) vessel diameter - VD (b) vessel frequency - FV.

Figura 7. Correlações entre caracterísiticas dos vasos em função da posição radial de Peltophorum dubium aos 28 anos de idade. (a) diâmetro do vaso - VD (b) frequência do vaso - FV.

As the wood anatomy is more conservative than the morphological characteristics, e.g., leaves, flowers, fruits, which are subject to greater selective pressure, variations in the wood are less clearly expressed than the external characteristics. Thus, we hypothesized that trees with different seed provenances to grow in the same place, maintain the wood structure from genetic information by the climatic conditions of origin place, despite new environmental requirements.

\section{CONCLUSIONS}

We did not observe changes in the basic specific gravity or anatomical features between the provenances, which may partly be explained by the conservative nature of wood compared with the external characteristics more susceptible to environmental stresses. Radial variation was similar to many native species that our group and others have studied, e.g., increase in basic specific gravity, fibers length and wall thickness and vessel diameter and decrease in vessel frequency toward the bark. Based on our results, it can be concluded that $P$. dubium trees from this study has high plant adaptability in different locations and that consistency in the quality of its wood can be maintained between provenances, with concomitant implications for both production and use.

\section{ACKNOWLEDGMENTS}

We are grateful to the National Council for Scientific and Technological Development - CNPq for a grant to Cintya Cerato, and we are especially grateful to Sonia Godoy Campião and Diego Romeiro for laboratory assistance.

\section{REFERENCES}

BAAS, P. et al. Evolution of xylem physiology. In: POOLE, I.; HEMSLEY, A. (Ed.). Evolution of plant physiology. London: Elsevier Academic Press, 2004. p. 273-295. (Linnean Society Symposium Series).

BENDTSEN, B.; SENFT, J. Mechanical and anatomical properties in individual growth rings of plantation-grown eastern Cottonwood and Loblolly Pine. Wood and Fiber Science, v. 18, p. 21-38,1986.

BERLYN, G.P.; MIKSCHE, J.P. Botanical microtechnique and cytochemistry. Ames: The Iowa University Press, 1976. 326 p.

CARVALHO, P.E.R. Espécies arbóreas brasileiras. Brasília, DF: Embrapa Informações Tecnológica: Colombo: Embrapa Floresta, 2003. $627 \mathrm{p}$. 
CHRISTENSEN-DALSGAARD, K.K.; ENNOS, A.R.; FOURNIER, M. Are radial changes in vascular anatomy mechanically induced or an ageing process? Evidence from observations on buttressed tree root systems. Trees, v. 22, p. 543-550, 2008.

CLIMATE-DATA.ORG. Dados climáticos para cidades mundiais. Available at: $<$ http://pt.climatedata.org/location/313031/>. Access on: Mar. 27, 2015.

GARTNER B.L. Patterns of xylem variation within a tree and their hydraulic and mechanical consequences. In: GARTNER, B.L. (Ed.). Plant stems: physiology and functional morphology. San Diego: Academic Press, 1995. p. 125-149.

GLASS, S.; ZELINKA, S.L. Moisture relations and physical properties of wood. In: ROSS, R. (Ed.). Wood handbook - wood as an engineering material. $100^{\text {th }}$ ed. Madison: U.S. Department of Agriculture, Forest Service, Forest Products Laboratory, 2010. 508 p. (General Technical Report FPL-GTR-190).

GURGEL-GARRIDO, L.M.A. et al. Programa de Melhoramento Genético Florestal do Instituto Florestal. IF Série Registros, n. 18, p. 1-53, 1997.

HIETZ, P.; VALENCIA, R.S.; WRIGHT, J. Strong radial variation in wood density follows a uniform pattern in two neotropical rain forests. Functional Ecology, v. 27, p. 684-692, 2013.

IAWA COMMITEE. List microscope features of hardwood identification. IAWA Bulletin, v. 10, p. 221-259, 1989.

JOHANSEN, D.A. Plant microtecniques. New York: McGraw-Hill, 1940. 523 p.

LACHENBRUCH, B.; JOHNSON, G.R.; EVANS, R. Relationships of density, microfibril angle, and sound velocity with stiffness and strength in mature wood of Douglas-fir. Can. J. For., v. 40, p. 55-64, 2010.

LEWIS, G.P. Peltophorum. In: LISTA de espécies da flora do Brasil. Jardim Botânico do Rio de Janeiro. Available at: <http://floradobrasil.jbrj. gov.br/jabot/floradobrasil/FB83567>. Acess on: Feb. 28, 2014.
LIMA, I.L. et al. Densidade básica e dimensões celulares da madeira de Balfourodendron riedelianum em função da procedência e posição radial. Revista do Instituto Florestal, v. 23, p. 217-230, 2011a.

et al. Variação radial da densidade básica e dimensões celulares da madeira de Cariniana legalis (Mart.) O. Kuntze em função da procedência. Cerne, v. 17, p. 517-524, 2011 b.

LONGUI, E.L. et al. Seed provenance influences the wood structure of Gallesia integrifolia. IAWA Journal, v. 32, p. 361-374, 2011.

LORENZI, H. Árvores brasileiras - manual de identificação e cultivo de plantas arbóreas nativas do Brasil, 4. ed. Nova Odessa: Instituto Plantarum, 2002. v. 1,368 p.

MAINIERI, C.; CHIMELO, J.P. Fichas de características das madeiras brasileiras. São Paulo: Instituto de Pesquisas Tecnológicas, 1989. $418 \mathrm{p}$.

MARQUES, S.S. et al. Estudo comparativo da massa específica aparente e retratibilidade da madeira de pau-brasil (Caesalpinia echinata LAM.) nativa e de reflorestamento. Revista Árvore, v. 36, n. 2, p. 373-80, 2012.

PANSHIN, A.J.; ZEEUW, C. de. Textbook of wood technology. New York: McGraw-Hill, 1964. 705 p.

PAULA, J.E. Madeiras da Caatinga úteis para produção de energia. Pesquisa Agropecuária Brasileira, v. 28, p. 153-165, 1983.

- Estudo de madeiras indígenas, visando seu aproveitamento na geração de energia. CNP-Atualidades, v. 92, p. 13-23, 1985.

.; ALVES, J.L. de H. Madeiras nativas. Brasília, DF: MOA, 2007. 541 p.

RICHTER, C. Wood characteristics: description, causes, prevention, impact on use and technological adaptation. Cham: Springer International Publishing Switzerland, 2015. 222 p.

S.A.S. INSTITUTE INC. SAS procedures guide. Version 8 (TSMO). Cary, 1999. 454 p. 
SILVA, J.C. Características da madeira de eucalipto.

Revista da Madeira, v. 52, p. 30-8, 2000.

SILVA, L.B.X.; REICHMANN NETO, F.; TOMASELLI, I. Estudo comparativo da produção de biomassa para energia entre 23 espécies florestais. Silvicultura, v. 28, p. 872-878, 1983.

SIQUEIRA, A.C.M.F. et al. Variação genética entre e dentro de populações de Balfourodendron riedelianum (Engler) Engler para conservação ex situ. Revista do Instituto Florestal, v. 12, p. 89-103, 2000.

VENTURA, A.; BERENGUT, G.; VICTOR, M.A.M. Características edafoclimáticas das dependências do Serviço Florestal do Estado de São Paulo. Silvicultura em São Paulo, v. 4, p. 57-140, 1965/1966.

VIVIAN, M.A. et al. Resistência da madeira de canafístula (Peltophorum dubium (Spreng.) Taub.) Ao psf e a umidade de equilíbrio. Ciência da Madeira, v. 1, p. 11-24, 2010.

WILliAMSON, G.B.; WIEMANN, M.C. Age versus size determination of radial variation in wood specific gravity: lessons from eccentrics. Trees, v. 25, p. 585-591, 2011. 